\title{
A field perspective on effects of fire and temperature fluctuation on Cerrado legume seeds
}

\author{
L. Felipe Daibes ${ }^{1 \star}$, Talita Zupo ${ }^{1}$, Fernando A.O. Silveira ${ }^{2}$ and Alessandra Fidelis ${ }^{1}$ \\ ${ }^{1}$ Universidade Estadual Paulista (UNESP), Instituto de Biociências, Departamento de Botânica, Av. 24-A 1515, \\ 13506-900, Rio Claro, Brazil; ${ }^{2}$ Universidade Federal de Minas Gerais (UFMG), Instituto de Ciências Biológicas, \\ Departamento de Botânica, CP 486, 31270-901, Belo Horizonte, Brazil
}

(Received 1 November 2016; accepted after revision 7 February 2017; first published online 3 April 2017)

\begin{abstract}
Information from a field perspective on temperature thresholds related to physical dormancy (PY) alleviation and seed resistance to high temperatures of fire is crucial to disentangle fire- and non-fire-related germination cues. We investigated seed germination and survival of four leguminous species from a frequently burned open Neotropical savanna in Central Brazil. Three field experiments were conducted according to seed location in/on the soil: (1) fire effects on exposed seeds; (2) fire effects on buried seeds; and (3) effects of temperature fluctuations on exposed seeds in gaps and shaded microsites in vegetation. After field treatments, seeds were tested for germination in the laboratory, together with the control (non-treated seeds). Fire effects on exposed seeds decreased viability in all species. However, germination of buried Mimosa leiocephala seeds was enhanced by fire in an increased fuel load treatment, in which we doubled the amount of above-ground biomass. Germination of two species (M. leiocephala and Harpalyce brasiliana) was enhanced with temperature fluctuation in gaps, but this condition also decreased seed viability. Our main conclusions are: (1) most seeds died when exposed directly to fire; (2) PY could be alleviated during hotter fires when seeds were buried in the soil; and (3) daily temperature fluctuations in gaps also broke PY of seeds on the soil surface, so many seeds could be recruited or die before being incorporated into the soil seed banks. Thus seed dormancy-break and germination of legumes from Cerrado open savannas seem to be driven by both fire and temperature fluctuations.
\end{abstract}

Keywords: campo sujo, experimental fire, Fabaceae, fireprone, Neotropical savanna, physical dormancy

\footnotetext{
* Correspondence

Email: luipedaibes@gmail.com
}

\section{Introduction}

Recruitment from seeds following fire is a key factor for the maintenance of populations of many species with physically dormant seeds throughout the world (e.g. Auld and O'Connell, 1991; Moreira and Pausas, 2012; Ooi et al., 2014). Physical dormancy (PY), or seed coat impermeability to water (Rolston, 1978; Baskin and Baskin, 2004; Finch-Savage and LeubnerMetzger, 2006), is common in many ecosystems and in many plant families, but it is especially relevant in tropical Fabaceae (Baskin et al., 2000; Jayasuriya et al., 2013; Baskin and Baskin, 2014). Although PY may have emerged as a response to distinct selective pressures rather than fire, such as drought and seasonality (Bradshaw et al., 2011; Santana et al., 2013; Willis et al., 2014; Jaganathan, 2015; Jayasuriya et al., 2015), its alleviation under natural conditions has been suggested to be fire dependent in many fire-prone habitats (Auld and O'Connell, 1991; Auld and Denham, 2006; Keeley et al., 2011; Moreira and Pausas, 2012; Ooi et al., 2014).

Nevertheless, daily temperature fluctuations may also play a role in PY alleviation in fire-prone ecosystems (Auld and Bradstock, 1996; Santana et al., 2010, 2013). Relatively high temperature fluctuations occur in post-fire vegetation due to increased solar irradiance (Auld and Bradstock, 1996; Fidelis and Blanco, 2014), but temperature fluctuations also occur in undisturbed vegetation gaps (Santana et al., 2013). On the other hand, there are many cases in which the temperature required to break PY is higher than those reached in vegetation gaps, and thus fire passage would be necessary to break dormancy (Moreira and Pausas, 2012). PY has been reported to be broken at different temperature thresholds, and these data have been used to classify species into functional groups according to their fire dependency: fire-obligate or fire-facultative, depending on the temperatures required to break PY (Ooi et al., 2014).

Determination of the temperature thresholds related to PY alleviation is crucial to disentangling 
the role of fire and temperature fluctuations as germination cues in fire-prone environments (Moreira and Pausas, 2012; Ooi et al., 2014), and it is also important to clarify seed tolerance to fire-related temperatures (Jaureguiberry and Díaz, 2015; Ribeiro et al., 2015). Moreover, it is necessary to determine such temperature thresholds from a field perspective (e.g. Santana et al., 2013). Therefore, if PY break is fire dependent, one should expect dormancy to be alleviated only at temperatures higher than those found in daily temperature fluctuations at the soil surface (Moreira and Pausas, 2012; Ooi et al., 2014).

The question regarding fire-mediated PY break has been mainly addressed in Australia (e.g. Auld and O'Connell, 1991; Knox and Clarke, 2006; Scott et al., 2010; Ooi et al., 2014) and Mediterranean vegetation (e.g. Herranz et al., 1998; Reyes and Trabaud, 2009; Moreira et al., 2010; Santana et al., 2013). In the Cerrado, few data are derived from field experiments (but see Hoffmann, 2000; Dodonov et al., 2014) and most data obtained from laboratory studies suggest that fire-related heat shock does not break PY (Ribeiro et al., 2015; Fichino et al., 2016; Zupo et al., 2016). Therefore, we still lack a comprehensive idea of the overall effects of fire on dormancy alleviation and seed germination in grassy biomes, which have been typically neglected (Parr et al., 2014). Such a field-related perspective should help us to understand germination responses to fire in the Neotropical savannas, such as the open Cerrado formations (campo sujo; Coutinho, 1982). The Cerrado is a Neotropical complex of open and closed savannas (Furley, 1999; OliveiraFilho and Ratter, 2002), where fire has been present for at least four million years (Simon et al., 2009).

Our purpose was to evaluate different scenarios for seed germination and survival from a field perspective, aiming to disentangle the role of fire-related and non-fire-related germination cues in a Neotropical savanna. Thus we carried out three field experiments with legume shrub seeds from Cerrado open savannas, according to where seeds could be located in/on the soil. Specifically, we tested the effects of (1) fire on exposed seeds (in the upper layer of the soil), (2) fire on buried seeds and (3) temperature fluctuations under non-fire-related conditions on dormancy break and maintenance of seed viability.

Additionally, we addressed the following hypotheses. (1) As recurrent Cerrado fires consume up to $90 \%$ of the grassy fuel load (Coutinho, 1982; Kauffman et al., 1994; Miranda et al., 2009), we expected fire to kill most of the seeds located on the soil surface, as reported for other fire-prone ecosystems (Carrington, 2010; Dayamba et al., 2010). (2) Belowground soil heating during fires could be increased by a higher amount of fuel load (Choczynska and Johnson, 2009; Gagnon et al., 2012, 2015), which in this case is the amount of live and dead grassy biomass, so we expected fires to have a positive effect on seed germination of buried seeds at increased fuel load conditions. (3) Natural temperature fluctuations, especially in vegetation gaps, could alleviate PY in the Cerrado, as reported for Australian legumes (Santana et al., 2010) and Mediterranean Basin obligate seeders (Santana et al., 2013).

\section{Materials and methods}

\section{Study site and seed collection}

Three separate field experiments (Table 1) were carried out at the Reserva Natural Serra do Tombador, in Central Brazil $\left(47^{\circ} 45^{\prime}-51^{\prime} \mathrm{W}\right.$ and $13^{\circ} 35^{\prime}-38^{\prime} \mathrm{S}, 8900$ ha, 560-1118 m above sea level). The area has been subjected to natural and anthropogenic fires, with a mean return interval of 3 years (Daldegan et al., 2014). The climate has a marked dry season from May to September (total precipitation during this period $<60 \mathrm{~mm}$ ) and a wet season from October to April, when most of the annual precipitation (1300-1500 mm/year) occurs. Annually, mean temperatures range from 22 to $25^{\circ} \mathrm{C}$ and September is usually the hottest month. Minimum temperatures may be $<15^{\circ} \mathrm{C}$ and maximum temperatures up to $36^{\circ} \mathrm{C}$ (Fundação Grupo Boticário, 2011). Vegetation is predominantly campo sujo, which is an open savanna dominated by a species-rich herbaceous layer with scattered shrubs and small trees (Coutinho, 1982).

We collected seeds from four leguminous shrub species commonly found in the area: Mimosa leiocephala Benth., Harpalyce brasiliana Benth., Senna corifolia (Benth.) H.S. Irwin and Barneby, and Bauhinia dumosa Benth. (Table 1). Seeds from all species were collected from several individuals $(n>10)$ and stored at $5^{\circ} \mathrm{C}$ for up to 1 year until the beginning of the experiments. All species had physically dormant seeds (Table 1), except B. dumosa, which has permeable seed coats (Zupo et al., 2016).

\section{Fire effects on exposed seeds}

We evaluated fire effects on survival of exposed seeds by carrying out experimental fires with seeds placed in the upper soil layer. The experiment was performed in July 2014 (mid-dry season), a period in which the study species are shedding seeds (authors' personal observation) and when most anthropogenic fires occur in the Cerrado (Ramos-Neto and Pivello, 2000; Miranda et al., 2009). We avoided patches invaded by Urochloa brizantha, an invasive African grass species, because it can influence fire parameters (Gorgone-Barbosa et al., 2015).

Seeds were placed in experimental plots subjected to fires (Fig. 1). We independently burned four distinct 
Table 1. Experiment set-up, species, date of collection, date of experiment, presence of dormancy and number of seeds per dish used in the tests at field conditions in an open savanna in Central Brazil

\begin{tabular}{|c|c|c|c|c|c|}
\hline Experiment & Species & $\begin{array}{c}\text { Seed collection } \\
\text { date }\end{array}$ & Date of experiment & Dormancy & $\begin{array}{l}\text { Seeds per } \\
\text { dish }(n)\end{array}$ \\
\hline \multirow[t]{4}{*}{ Fire effects on exposed seeds } & Mimosa leiocephala & October 2013 & \multirow[t]{4}{*}{ July 2014 (mid-dry season) } & PY & 10 \\
\hline & Harpalyce brasiliana & July 2013 & & PY & 10 \\
\hline & Senna corifolia & October 2013 & & PY & 9 \\
\hline & Bauhinia dumosa & October 2013 & & ND & 8 \\
\hline \multirow[t]{2}{*}{ Fire effects on buried seeds } & Mimosa leiocephala & October 2014 & \multirow[t]{2}{*}{ October 2015 (late-dry season) } & PY & 10 \\
\hline & Bauhinia dumosa & October 2015 & & ND & 10 \\
\hline \multirow[t]{4}{*}{ Temperature fluctuation effects } & Mimosa leiocephala & October 2013 & \multirow[t]{4}{*}{ July-October 2014 (dry season) } & PY & 10 \\
\hline & Harpalyce brasiliana & July 2013 & & PY & 10 \\
\hline & Senna corifolia & October 2013 & & PY & 9 \\
\hline & Bauhinia dumosa & October 2013 & & ND & 8 \\
\hline
\end{tabular}

PY, physical dormancy; ND, non-dormant.

plots $(15 \times 20 \mathrm{~m}$, excluded from fire for 2 years), which were located at least $20 \mathrm{~m}$ from each other. Seeds were placed in aluminium dishes $(7 \mathrm{~cm}$ diameter $\times 0.5 \mathrm{~cm}$ deep) filled with local soil and positioned on the soil surface. Seeds were carefully placed within the aluminium dishes, so that they would have at least part of their seed coat exposed directly to fire. Three aluminium dishes were placed under the native vegetation (grass tussocks) in each plot ( 3 dishes $\times 4$ plots $=12$ samples). We conducted head fires (wind direction), and fires were set in the morning for safety reasons (Whelan, 1995); all plots were burned in the same week. Fire temperatures were recorded every $2 \mathrm{~s}$ with type $\mathrm{K}$ thermocouple sensors attached to data loggers (Novus LogBox). We calculated fire residence times at temperatures $\geq 60^{\circ} \mathrm{C}$, which is a standardized temperature threshold lethal for plant tissue (Daniell et al., 1969; Dayamba et al., 2010). Additionally, we calculated residence time of fire temperatures $\geq 100^{\circ} \mathrm{C}$, a threshold easily reached by fire under exposed conditions. The number of seeds per dish varied between species due to constraints in seed availability (see Table 1). Control seeds were transported to the field and kept stored in thermal bags at room temperature, thus not heated. After fires, both control and treatment seeds were tested for germination in the laboratory (see germination procedures below).

\section{Fire effects on buried seeds}

To test the effects of fire on the survival and germination of buried seeds, we used seeds of two species with different traits in relation to seed coat permeability: one with impermeable-coated seeds (PY, $M$. leiocephala) and the other with permeable seeds (non-dormant, B. dumosa, see Table 1). Since the amount of fuel (live and dead grassy species) can influence both fire intensity and temperatures reached during fires (Gagnon et al., 2015; M.N. Rissi et al., unpublished data), we manipulated the fuel load to assess the effects of doubling the amount of aboveground biomass on soil heating and thus on seed germination and survival of buried seeds. Therefore, the following treatments were carried out in the field: (1) no manipulation of fuel load $\left(\sim 700 \mathrm{~g} \mathrm{~m}^{-2}\right)$ and (2) increased fuel load by adding $700 \mathrm{~g} \mathrm{~m}^{-2}$ of biomass collected from neighbouring plots to double the fuel load. For this treatment, four $30 \times 30 \mathrm{~m}$ plots were individually burned, and we established three subplots $(2 \times 2 \mathrm{~m})$ for each biomass manipulation treatment within each plot ( 3 subplots $\times 4$ plots $=12$ subplots/ treatment). In each subplot, we placed an aluminium dish with 10 seeds/species buried $1 \mathrm{~cm}$ below ground (Fig. 1; Table 1). Fires were set in October 2015 (late-dry season), using experimental procedures similar to those described above, and fire temperatures were recorded (type $\mathrm{K}$ thermocouple sensors attached to data loggers) every $2 \mathrm{~s}$ at $1 \mathrm{~cm}$ below ground in each subplot/treatment. However, measurements in most sensors at the increased fuel load treatment failed and therefore they are not presented in detail. Control seeds were transported to the field, but kept stored at room temperature, and after fires both control and treatment seeds were tested for germination in the laboratory (see below).

\section{Temperature fluctuation effects}

We used seeds of the four species at two different field treatments to test the effects of temperature fluctuations on seed germination: (1) shaded: seeds placed under native grass tussocks; and (2) gap: seeds placed in bare soil gaps. The soil-filled aluminium dishes $(0.5$ $\mathrm{mm}$ deep) with seed samples were placed at soil level in shade or in a gap in the field for ca 75 days from July to October (dry season). Soil temperatures were recorded every $30 \mathrm{~min}$ by sensors coupled to data loggers. The sensors were placed at the soil surface in each 
Fire effects on exposed seeds

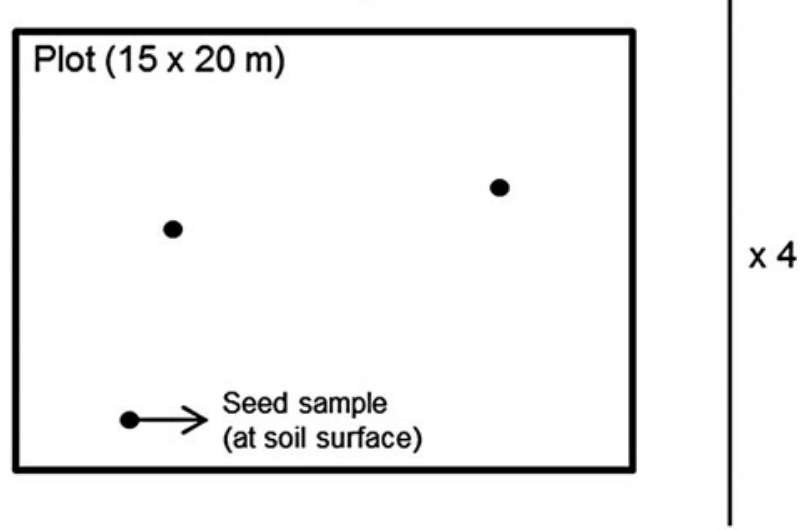

Fire effects on buried seeds

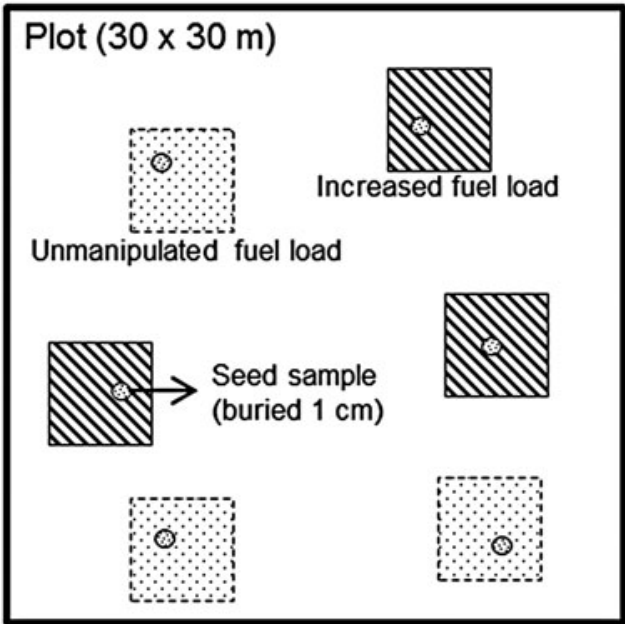

\section{Temperature fluctuation effects}

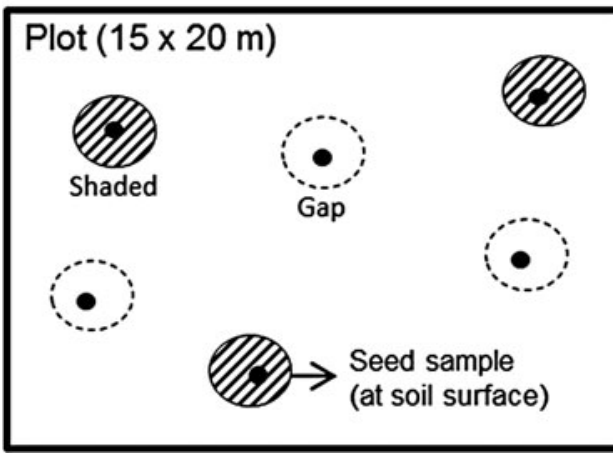

Figure 1. Experimental design of the different experiments tested under field conditions in an open savanna in Central Brazil: (1) fire effects on exposed seeds; (2) fire effects on buried seeds at different fuel load treatments: unmanipulated and increased amount of above-ground biomass; and (3) temperature fluctuations in shaded and gap conditions. Black circles show aluminium dishes containing seed samples at soil surface, and grey dotted circles show aluminium dishes containing seed samples at $1 \mathrm{~cm}$ below ground. Number of seeds per species/sample is shown in Table 1. treatment, near the aluminium dishes: in the shaded treatment, sensors were placed under tussocks of native grasses; and in the gap treatment they were exposed to sunlight. The treatments were applied in four unburned plots and followed the same experimental design as described above ( 3 dishes $\times 4$ plots $=12$ samples/treatment; Fig. 1; Table 1). After 75 days, treatment and control (stored at room temperature) seeds were tested for germination, as described below.

\section{Germination tests after field treatments}

Upon the completion of the field treatments, seeds were packed in thermal bags and immediately transported to the laboratory. Treatment and control seeds were then placed in Petri dishes (60 mm diameter) with a double layer of filter paper saturated with distilled water and set to germinate in germination chambers at $27^{\circ} \mathrm{C}$ (12 h of light); the average temperature was recorded at soil level in the study site and in accordance with other studies performed with Cerrado seeds (Fichino et al., 2016). We used a constant temperature to avoid possible additional effects of alternating temperature in seed germination. Seeds were considered germinated when exhibiting radicle protrusion (Bewley et al., 2013) and germination was recorded three times a week for four consecutive weeks.

At the end of the germination tests, non-germinated seeds were scarified, allowed to imbibe and then cut and tested for the viability using tetrazolium solution (1\%, buffer $\mathrm{pH} 7)$. Seeds with embryos that stained red were considered to be viable, and those with nonstained embryo or those that were visibly burned or showed flaccid tissues were considered to be dead (Lakon, 1949).

\section{Data analyses}

All our experiments followed a similar experimental design (Fig. 1), with the seed samples nested within the experimental plots ( 3 dishes $\times 4$ plots $=12$ samples/ species/treatment). Therefore, we performed generalized linear mixed models (GLMMs) with a binomial distribution (see Santana et al., 2013) to separately evaluate: seed germination (binary data considering that a seed could germinate or not) and seed viability (a seed could be viable or not at the end of the trials). As the dishes were nested within the plots, they were considered as the random effects in the analyses. The field treatments (fire treatments or shaded/gap temperature fluctuations, as well as their respective controls) were treated as fixed effects. The controls were considered as the baseline for the intercept in the models. Models were fitted for each species separately in 
each experiment. Post hoc Tukey's tests were performed to evaluate multiple comparisons among treatments. All analyses were performed using the packages lme4 (Bates et al., 2015) and multcomp (Hothorn et al., 2008) in R software 3.2.5 (R Core Team, 2016) and significance was determined with $\alpha=0.05$.

\section{Results}

\section{Fire effects on exposed seeds}

Maximum fire temperatures were $225 \pm 152^{\circ} \mathrm{C}$, with residence time of temperatures $\geq 60^{\circ} \mathrm{C}$ equal to $80 \pm$ $26 \mathrm{~s}$ and $\geq 100^{\circ} \mathrm{C}$ always less than $1 \mathrm{~min}$. For M. leiocephala, germination decreased from $26 \pm 9 \%$ (control) to $9 \pm 7 \%$ [fire treatment, $P=0.002$; Table 2 (a); Fig. $2 \mathrm{~A}$ ]. Germination of H. brasiliana and S. corifolia was nearly null in both the control and the fire exposure treatments [Table 2 (a); Fig. 2A]. However, for B. dumosa, a species with permeable seeds, fire exposure reduced germination from $88 \pm 4$ to $11 \pm 22 \%$ [ $(P<0.001)$; Table 2 (a); Fig. 2A]. Initial seed viability ranged from $63 \%(H$. brasiliana) to $90 \%$ (B. dumosa), and seed viability of all four species decreased after fire exposure to less than $30 \%$ [all $(P<0.001)$; Table 2 (a); Fig. 2B].

\section{Fire effects on buried seeds}

Below-ground temperatures reached mean maxima of $54 \pm 14^{\circ} \mathrm{C}$, and thus they did not exceed the threshold of $60^{\circ} \mathrm{C}$ for residence time calculations in the unmanipulated treatment. Sensors failed to measure below-ground temperatures in the increased fuel load condition, however; recordings of fire temperatures in the same area point out that mean maxima temperatures reach around $80^{\circ} \mathrm{C}$ at $1 \mathrm{~cm}$ depth in sites under high biomass accumulation (see Discussion).

Regarding seed germination, there was no difference in germination percentage of $M$. leiocephala seeds between the control $(5 \pm 4 \%)$ and the unmanipulated treatment $[3 \pm 5 \%$, Table 2 (b); Fig. $3 \mathrm{~A}]$. Moreover, the increased fuel load treatment had a positive effect on

Table 2. Parameters estimated by the GLMM models for seed germination and viability of four legume shrub species exposed to: fire effects on exposed seeds (a); fire effects on buried seeds (b); and temperature fluctuations (c), in an open savanna in Central Brazil

\begin{tabular}{|c|c|c|c|c|c|c|c|c|}
\hline \multirow[b]{2}{*}{ Experiment } & \multirow[b]{2}{*}{ Species } & \multirow[b]{2}{*}{ Treatment } & \multicolumn{3}{|c|}{ Seed germination } & \multicolumn{3}{|c|}{ Seed viability } \\
\hline & & & Estimate & SEM & $P$-value & Estimate & SEM & $P$-value \\
\hline \multirow{8}{*}{$\begin{array}{l}\text { Fire effects on exposed } \\
\text { seeds (a) }\end{array}$} & \multirow[t]{2}{*}{ Mimosa leiocephala } & Intercept & -1.093 & 0.264 & $<0.001$ & 2.034 & 0.736 & 0.006 \\
\hline & & Fire & -1.362 & 0.448 & 0.002 & -3.862 & 1.051 & $<0.001$ \\
\hline & \multirow[t]{2}{*}{ Harpalyce brasiliana } & Intercept & -3.136 & 0.457 & $<0.001$ & 0.632 & 0.696 & 0.364 \\
\hline & & Fire & -1.644 & 1.103 & 0.136 & -4.051 & 1.202 & $<0.001$ \\
\hline & \multirow[t]{2}{*}{ Senna corifoilia } & Intercept & -2.632 & 0.522 & $<0.001$ & 1.344 & 0.436 & 0.002 \\
\hline & & Fire & -2.020 & 1.133 & 0.075 & -2.357 & 0.621 & $<0.001$ \\
\hline & \multirow{2}{*}{ Bauhinia dumosa } & Intercept & 2.331 & 0.873 & 0.008 & 2.530 & 0.874 & 0.004 \\
\hline & & Fire & -6.2931 & 1.615 & $<0.001$ & -6.468 & 1.604 & $<0.001$ \\
\hline \multirow{6}{*}{$\begin{array}{l}\text { Fire effects on buried } \\
\text { seeds (b) }\end{array}$} & \multirow[t]{3}{*}{ Mimosa leiocephala } & Intercept & -3.700 & 0.729 & $<0.001$ & 1.418 & 0.339 & $<0.001$ \\
\hline & & Unmanipulated & -0.565 & 1.151 & 0.578 & -0.031 & 0.476 & 0.950 \\
\hline & & Increased & 2.225 & 0.869 & 0.011 & -0.339 & 0.469 & 0.470 \\
\hline & \multirow[t]{3}{*}{ Bauhinia dumosa } & Intercept & 6.058 & 1.496 & $<0.001$ & 6.058 & 1.496 & $<0.001$ \\
\hline & & Unmanipulated & -2.250 & 1.511 & 0.137 & -2.250 & 1.511 & 0.137 \\
\hline & & Increased & -2.434 & 1.510 & 0.107 & -2.434 & 1.510 & 0.107 \\
\hline \multirow{12}{*}{$\begin{array}{l}\text { Temperature fluctuation } \\
\text { effects (c) }\end{array}$} & \multirow{3}{*}{ Mimosa leiocephala } & Intercept & -1.098 & 0.272 & $<0.001$ & 1.874 & 0.398 & $<0.001$ \\
\hline & & Shaded & -0.641 & 0.406 & 0.114 & -0.381 & 0.549 & 0.488 \\
\hline & & Gap & 1.435 & 0.376 & $<0.001$ & -1.231 & 0.535 & 0.021 \\
\hline & \multirow[t]{3}{*}{ Harpalyce brasiliana } & Intercept & -3.216 & 0.489 & $<0.001$ & 0.551 & 0.293 & 0.060 \\
\hline & & Shaded & 0.947 & 0.579 & 0.102 & -0.121 & 0.413 & 0.769 \\
\hline & & Gap & 1.754 & 0.546 & 0.001 & -0.900 & 0.414 & 0.030 \\
\hline & \multirow[t]{3}{*}{ Senna corifolia } & Intercept & -2.543 & 0.393 & $<0.001$ & 1.192 & 0.306 & $<0.001$ \\
\hline & & Shaded & -1.318 & 0.815 & 0.106 & 0.065 & 0.423 & 0.879 \\
\hline & & Gap & 0.156 & 0.539 & 0.772 & -1.402 & 0.415 & $<0.001$ \\
\hline & \multirow{3}{*}{ Bauhinia dumosa } & Intercept & 1.989 & 0.296 & $<0.001$ & 2.190 & 0.334 & $<0.001$ \\
\hline & & Shaded & -0.682 & 0.378 & 0.071 & -0.425 & 0.440 & 0.335 \\
\hline & & Gap & -1.788 & 0.358 & $<0.001$ & -1.780 & 0.403 & $<0.001$ \\
\hline
\end{tabular}

Significant $P$-values $(\leq 0.05)$ are highlighted in bold. 

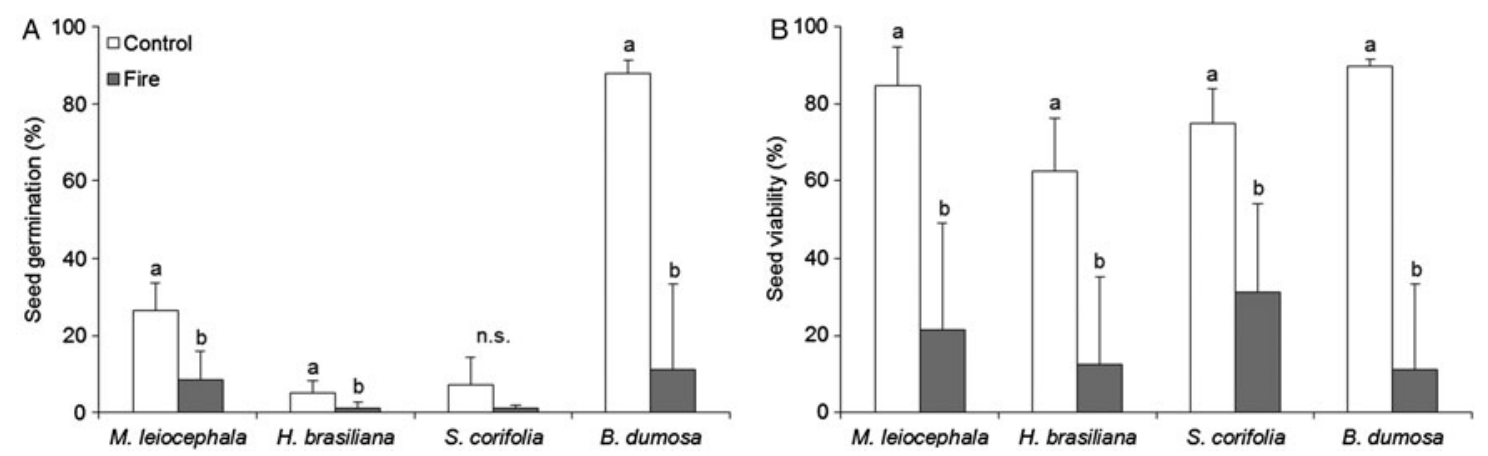

Figure 2. Fire effects on exposed seeds: (A) seed germination and (B) seed viability (\%, mean \pm SD) of four leguminous shrub species from an open savanna subjected to experimental fires in Central Brazil. Control refers to untreated seeds, set to germinate in the laboratory. Different letters $(a, b)$ denote significant differences $(P \leq 0.05)$ among treatments; statistical comparisons were performed separately for each species; n.s., not significant.

seed germination of $M$. leiocephala, resulting in a 6-fold increase in germination $[P=0.011$; Table 2 (b); Fig. 3A]. There was no difference in seed viability among treatments for this species [Table 2 (b)], which was over $70 \%$ for all treatments (Fig. 3B). For B. dumosa seeds, both seed germination and viability percentages were not affected by the treatments [Table 2 (b)], remaining $\geq 88 \%$ (Fig. $3 \mathrm{~A}$ and B).

\section{Temperature fluctuation effects}

Soil temperature under the shaded condition ranged from 20 to $38^{\circ} \mathrm{C}$ (Fig. 4) and had little or no effect on seed germination for any species [Table 2 (c); Fig. 5A]. On the other hand, soil temperature in gaps ranged from 18 to $53^{\circ} \mathrm{C}$ and remained $\geq 50^{\circ} \mathrm{C}$ for at least $2 \mathrm{~h}$ each day (Fig. 4).

Temperature fluctuations in the gap treatment had a positive effect in alleviating $\mathrm{PY}$ in $M$. leiocephala $(P<0.001)$ and $H$. brasiliana $[P=0.001$; Table 2 (c)]. For $M$. leiocephala, the gap condition enhanced germination percentage $(58 \pm 17 \%)$ in relation to both shaded treatments $(16 \pm 4 \%)$ and the control $(26 \pm 9 \%$; Fig. 5A). For H. brasiliana, the gap condition increased germination to $20 \pm 5 \%$ compared with the control $(5 \pm 3 \%$, Fig. $5 \mathrm{~A})$. However, none of the treatments alleviated dormancy in S. corifolia seeds [Table 2 (c); Fig. 5A]. Seeds of B. dumosa were negatively affected by temperature fluctuation in the gaps $[P<0.001$; Table 2 (c); Fig. 5A].

Seed viability of all species in the shaded treatment did not differ from their respective controls [Table 2 (c); Fig 5B]. Nonetheless, the gap treatment had a negative effect on seed viability from 20 to $30 \%$ across species [Table 2 (c); Fig. 5B].

\section{Discussion}

There is an ongoing debate on the relative importance of fire-related temperatures $v s$ daily temperature fluctuations in alleviating PY in fire-prone ecosystems (Moreira et al., 2010; Santana et al., 2010, 2013; Ooi et al., 2014), and our study helps to disentangle these germination cues from a field perspective in a
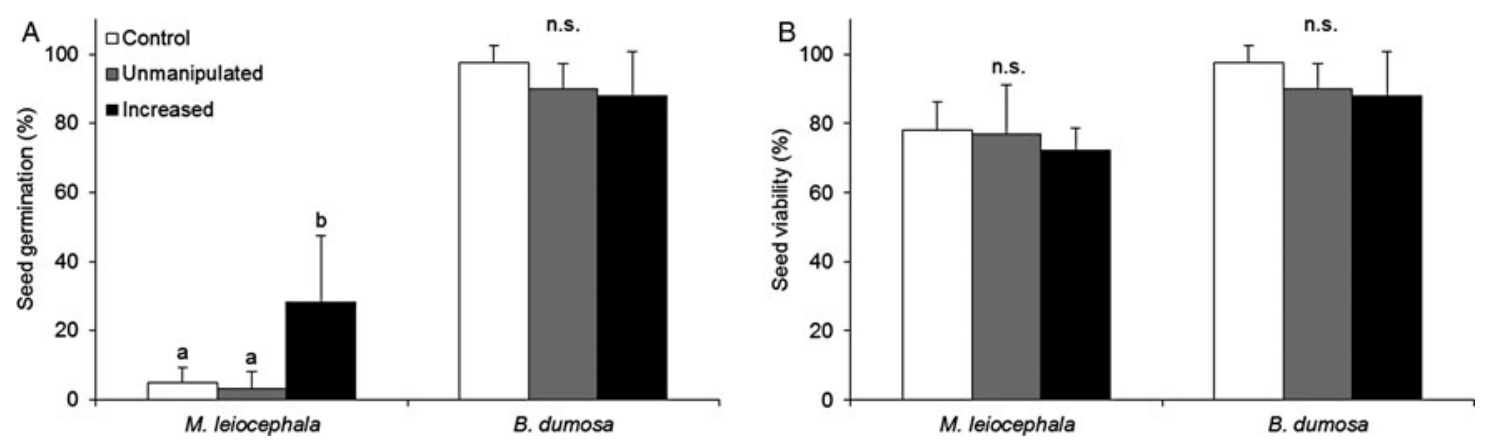

Figure 3. Fire effects on buried seeds: (A) seed germination and (B) seed viability (\%, mean \pm SD) of buried seeds $(1 \mathrm{~cm}$ below ground) of two legume shrub species from an open savanna, subjected to experimental fires in Central Brazil. Control: untreated seeds, set to germinate in the laboratory; Unmanipulated: treatment with no manipulation of fuel load; Increased: above-ground biomass was manipulated to double its average amount. Different letters $(a, b)$ denote significant differences $(P \leq 0.05)$ among treatments; statistical comparisons were performed separately for each species; n.s., not significant. 


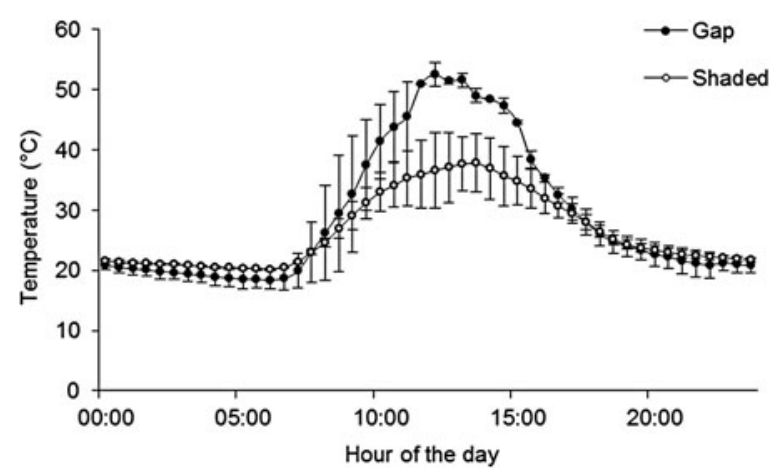

Figure 4. Daily temperature fluctuations (mean $\pm \mathrm{SD}$ ) at the soil surface under vegetation gaps (filled circles) and under shaded conditions (open circles) in an open savanna in Central Brazil for 75 days in the dry season (July to October 2014).

Neotropical savanna. Theoretically, PY should be broken at different temperature thresholds, so dormancy alleviation could be classified as being fire related or not (Moreira and Pausas, 2012; Ooi et al., 2014). However, we argue that Cerrado leguminous seeds have their PY (or at least part of it) alleviated by two different mechanisms: (1) during hotter fires, if seeds are stored in the soil, or (2) when exposed to daily temperature fluctuations.

Although not tested under the buried conditions in our field experiments, some seeds of $H$. brasiliana have part of their PY alleviated after heat shocks applied in the laboratory (H.L. Zirondi et al., unpublished data). Therefore, seeds of both M. leiocephala and H. brasiliana should be classified as facultative regarding their functional responses to fire (see Ooi et al., 2014). PY of $S$. corifolia seeds, on the other hand, was neither alleviated from laboratory heat shocks (data not shown) nor from the enhanced field temperature fluctuations, which could suggest that these legume seeds have other habitat-specific dormancy-breaking mechanisms under natural conditions, perhaps related to wetter conditions (van Klinken and Goulier, 2013).

Fire effects on exposed seeds caused a high mortality, as reported for most seeds throughout the world when placed in the upper layer of the soil (Auld and O'Connell, 1991; Bradstock and Auld, 1995; Carrington, 2010; Dayamba et al., 2010). However, seeds buried in the soil would be insulated and could have PY alleviated, as reported for Australian leguminous seeds (Auld and O'Connell, 1991; Bradstock and Auld, 1995). Conversely, below-ground temperatures required for PY break seem to be only reached under more intense fires (Knox and Clarke, 2006). Despite that, Cerrado fires are mostly fast and below-ground soil heating is usually negligible $\left(\sim 50^{\circ} \mathrm{C}\right.$; Miranda et al., 1993), with minor consequences to the seed bank (Andrade and Miranda, 2014).

Nevertheless, hotter fires may occur in the Cerrado when the return intervals take 4 years or more, due to a substantial accumulation of fuel load (Coutinho, 1982), which would also enhance below-ground fire temperatures, as reported for other high-diversity flammable communities (e.g. Gagnon et al., 2015). In our study area, previous measurements of fire temperatures $1 \mathrm{~cm}$ below ground in plots with 4 years of fuel load accumulation, detected temperatures reaching $\geq 60^{\circ} \mathrm{C}$ for about $3 \mathrm{~min}$, occasionally recording temperatures $\geq 100^{\circ} \mathrm{C}$ (mean maxima $=80^{\circ} \mathrm{C}$; maximum observed $=$ $154^{\circ} \mathrm{C}$; T. Zupo et al., unpublished data). On the other hand, anthropogenic fires have been suggested to change fire regimes in Cerrado open savannas, by shifting season of occurrence from wet to the dry season and shortening the frequency of return (RamosNeto and Pivello, 2000; Miranda et al., 2009).

Fire-stimulated germination traits should not have been favoured in fire-prone systems that undergo surface fires (Bond and Midgley, 2003; Bradshaw et al., 2011), such as the open savannas where fire episodes are frequent and less severe (Bond and Keeley, 2005).
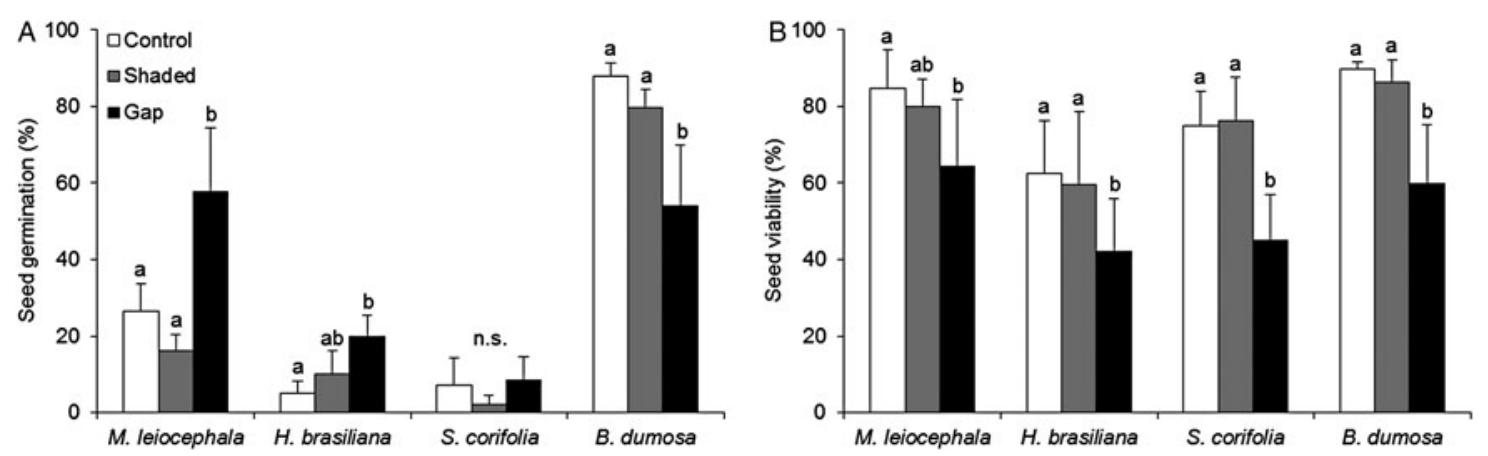

Figure 5. Temperature fluctuation effects (A) on seed germination and (B) on seed viability (\%, mean \pm SD) of four legume shrub species from an open savanna, subjected to daily temperature fluctuation in Central Brazil for 75 days. Control: untreated seeds, set to germinate in the laboratory; Shaded: temperature fluctuations under the shade of grasses; Gap: temperature fluctuations in the gaps of bare soil. Different letters $(a, b)$ denote significant differences $(P \leq 0.05)$ among treatments; statistical comparisons were performed separately for each species. 
Although there has been no evidence of fire-stimulated germination from laboratory experiments (Le Stradic et al., 2015; Ribeiro et al., 2015; Fichino et al., 2016; Zupo et al., 2016), we argue that fire-related conditions can potentially break PY, as was observed in at least $30 \%$ of $M$. leiocephala buried seeds under increased fuel load conditions. Therefore, fire could play a role in seed recruitment for a proportion of seeds from the Cerrado soil seed bank.

Fire also has been recognized as having an indirect effect on PY alleviation by removing vegetation and consequently increasing daily temperatures at upper soil layers $(\sim 0.5 \mathrm{~cm})$, therefore reaching temperature thresholds required for gap-dependent seeds to break PY (Ooi et al., 2014), which do not seem to occur in vegetated sites (Auld and Bradstock, 1996; Santana et al., 2010). However, gaps in unburned sites seem to have the same effect in seedling recruitment, suggesting that biomass removal, which increases the daily temperature fluctuations, plays a role in regeneration from seeds irrespective of fire (Santana et al., 2013).

Previous laboratory simulations of temperature fluctuations had already recognized a decrease in germination in the permeable-coated $B$. dumosa seeds, but such experiments had no effect on PY alleviation of $M$. leiocephala (Zupo et al., 2016). Instead, our results show that temperature fluctuation in gaps enhanced germination for $M$. leiocephala and $H$. brasiliana seeds, even though PY was not fully alleviated. Thus, from a field perspective, vegetation gaps provide an important micro-environment with higher temperature fluctuations that could lead to the alleviation of PY in legume seeds, enabling their germination in both post-fire environments (where temperature fluctuations will be higher due to the removal of the above-ground vegetation), as well as in fire-free intervals if seeds reach such gaps.

PY release has not yet been fully explained for Cerrado open savannas. Our four study species are dominant in their plant community, and distinct traits related to dormancy relief and germination strategies could explain a diversity of regeneration niches and species co-existence (see Grubb, 1977). Therefore, other species-specific processes may be related to releasing PY in these species. Further studies are warranted to understand if water availability could play any role coupled with daily heating temperatures (Moreno-Casasola et al., 1994; van Klinken et al., 2006), and if seeds could become sensitive to dormancybreaking conditions as they age in soil seed banks (van Assche et al., 2003; Jayasuriya et al., 2009; GamaArachchige et al., 2012; Liyanage and Ooi, 2017).

This was the first attempt to test fire- and non-firerelated cues of seed germination within an experimental field approach for the Cerrado open savannas. We draw three main conclusions from our experiments: (1) most seeds die when exposed directly to fire; (2) PY could be alleviated during hotter fires when seeds were buried, and thus stored in the soil seed bank; and (3) daily temperature fluctuations in gaps also break PY in seeds of some species on the soil surface, and thus many seeds may germinate or die instead of being incorporated into the soil seed banks.

\section{Acknowledgements}

We thank the fire team from the Reserva Natural Serra do Tombador: A.F. Terra, G.A. Berberino, R.B. de Almeida and S.A. Borges. We also thank E. GorgoneBarbosa, M.N. Rissi and M.B. Cunha for the collaboration in field work. The first author holds a scholarship from Coordenação de Aperfeiçoamento de Pessoal de Nível Superior (CAPES). This study was funded by Fundação de Amparo à Pesquisa do Estado de São Paulo (FAPESP 2015/06743-0), Conselho Nacional de Desenvolvimento Científico e Tecnológico (CNPq 455183/2014-7) and Fundação Grupo Boticário (0153 2011_PR; 0106_2011_PR). F.A.O. Silveira (482720/ 2014) and A. Fidelis (306170/2015-9) received research grants from $\mathrm{CNPq}$.

\section{References}

Andrade, L.A.Z. and Miranda, H.S. (2014) The dynamics of the soil seed bank after a fire event in a woody savanna in central Brazil. Plant Ecology 215, 1199-1209.

Auld, T.D. and Bradstock, R.A. (1996) Soil temperatures after the passage of a fire: do they influence the germination of buried seeds? Australian Journal of Ecology 21, 106-109.

Auld, T.D. and Denham, A.J. (2006) How much seed remains in the soil after a fire? Plant Ecology 187, 15-24.

Auld, T.D. and O'Connell, M.A. (1991) Predicting patterns of post-fire germination in 35 eastern Australian Fabaceae. Australian Journal of Ecology 16, 53-70.

Baskin, C.C. and Baskin, J.M. (2014) Seeds: Ecology, Biogeography, and Evolution of Dormancy and Germination, 2nd edition. San Diego, USA: Academic Press.

Baskin, J.M. and Baskin, C.C. (2004) A classification system for seed dormancy. Seed Science Research 14, 1-16.

Baskin, J.M., Baskin, C.C. and Li, X. (2000) Taxonomy, anatomy and evolution of physical dormancy in seeds. Plant Species Biology 15, 139-152.

Bates, D., Maechler, M., Bolker, B. and Walker, S. (2015) Fitting linear mixed-effects models using lme4. Journal of Statistical Software 67, 1-48.

Bewley, J.D., Bradford, K., Hilhorst, H.W.M. and Nonogaki, H. (2013) Seeds: Physiology of Development, Germination and Dormancy, 3rd edition. New York, USA: Springer Science.

Bond, W.J. and Keeley, J.E. (2005) Fire as a global 'herbivore': the ecology and evolution of flammable ecosystems. Trends in Ecology and Evolution 20, 387-394.

Bond, W.J. and Midgley, J.J. (2003) The evolutionary ecology of sprouting in woody plants. International Journal of Plant Sciences 164, 103-114.

Bradshaw, S.D., Dixon, K.W., Hopper, S.D., Lambers, H. and Turner, S.R. (2011) Little evidence for fire-adapted 
plant traits in Mediterranean climate regions. Trends in Plant Science 16, 69-76.

Bradstock, R.A. and Auld, T.D. (1995) Soil temperatures during experimental bushfires in relation to fire intensity: consequences for legume germination and fire management in South-Eastern Australia. Journal of Applied Ecology 32, 76-84.

Carrington, M.E. (2010) Effects of soil temperature during fire on seed survival in Florida sand pine scrub. International Journal of Forestry Research. doi: 10.1155/ 2010/402346

Choczynska, J. and Johnson, E.A. (2009) A soil heat and water transfer model to predict belowground grass rhizome bud death in a grass fire. Journal of Vegetation Science 20, 277-287.

Coutinho, L.M. (1982) Ecological effects of fire. In Huntley, B.J. and Walker, B.H. (eds), Ecology of Tropical Savannas, pp. 273-291. Berlin: Springer-Verlag.

Daldegan, G.A., Carvalho Júnior, O.A., Guimarães, R.F., Gomes, R.A.T., Ribeiro, F.F. and McManus, C. (2014) Spatial patterns of fire recurrence using remote sensing and GIS in the Brazilian savanna: Serra do Tombador Nature Reserve, Brazil. Remote Sensing 6, 9873-9894.

Daniell, J.W., Chappell, W.E. and Couch, H.B. (1969) Effect of sublethal and lethal temperatures on plant cells. Plant Physiology 44, 1684-1689.

Dayamba, S.D., Savadogo, P., Zida, D., Sawadogo, L., Tiveau, D. and Oden, PC. (2010) Fire temperature and residence time during dry season burning in a Sudanian savanna-woodland of West Africa with implication for seed germination. Journal of Forestry Research 21, 445-450.

Dodonov, P., Xavier, R.O., Tiberio, F.C.S., Lucena, I.C., Zanelli, C.B. and Matos, D.M.S. (2014) Driving factors of small-scale variability in a savanna plant population after a fire. Acta Oecologica 56, 47-55.

Fichino, B., Dombrovski, J.R.G., Pivello, V.R. and Fidelis, A. (2016) Does fire trigger seed germination in the Neotropical savannas? Experimental tests with six Cerrado species. Biotropica 48, 181-187.

Fidelis, A. and Blanco, C. (2014) Does fire induce flowering in Brazilian subtropical grasslands? Applied Vegetation Science 17, 690-699.

Finch-Savage, W.E. and Leubner-Metzger, G. (2006) Seed dormancy and the control of germination. New Phytologist 171, 501-523.

Fundação Grupo Boticário (2011) Plano de Manejo da Reserva Natural Serra do Tombador. Supervisor: G.A. Gatti. Curitiba, Brazil. Available at: http://www.fundacaogrupoboticario.org.br

Furley, P.A. (1999) The nature and diversity of neotropical savanna vegetation with particular reference to the Brazilian cerrados. Global Ecology and Biogeography 8, 223-241.

Gagnon, P.R., Harms, K.E., Platt, W.J., Passmore, H.A. and Myers, J.A. (2012) Small-scale variation in fuel loads differentially affects two co-dominant bunchgrasses in a species-rich pine savanna. PLoS ONE 7, e29674.

Gagnon, P.R., Passmore, H.A., Slocum, M., Myers, J.A., Harms, K.E., Platt, W.J. and Paine, C.E.T. (2015) Fuels and fires influence vegetation via above- and belowground pathways in a high-diversity plant community. Journal of Ecology 103, 1009-1019.

Gama-Arachchige, N.S., Baskin, J.M., Geneve, R.L. and Baskin, C.C. (2012) The autumn effect: timing of physical dormancy break in seeds of two winter annual species of
Geraniaceae by a stepwise process. Annals of Botany 110, 637-651.

Gorgone-Barbosa, E., Pivello, V.R., Bautista, S., Zupo, T., Rissi, M.N. and Fidelis, A. (2015) How can an invasive grass affect fire behavior in a tropical savanna? A community and individual plant level approach. Biological Invasions 17, 423-431.

Grubb, P. J. (1977) The maintenance of species-richness in plant communities: the importance of the regeneration niche. Biological Reviews 52, 107-145.

Herranz, J.M., Ferrandis, P. and Martínez-Sánchez, J.J. (1998) Influence of heat on seed germination of seven Mediterranean Leguminosae species. Plant Ecology 136, 95-103.

Hoffmann, W.A. (2000) Post-establishment seedling success in the Brazilian Cerrado: a comparison of savanna and forest species. Biotropica 32, 62-69.

Hothorn, T., Bretz, F. and Westfall, P. (2008) Simultaneous inference in general parametric models. Biometrical Journal 50, 346-363.

Jaganathan, G.K. (2015) Are wildfires an adapted ecological cue breaking physical dormancy in the Mediterranean basin? Seed Science Research 25, 120-126.

Jaureguiberry, P. and Díaz, S. (2015) Post-burning regeneration of the Chaco seasonally dry forest: germination response of dominant species to experimental heat shock. Oecologia 177, 689-699.

Jayasuriya, K.M.G.G., Athugala, Y.S., Wijayasinghe, M.M., Baskin, J.M., Baskin, C.C. and Mahadevan, N. (2015) The crypsis hypothesis: a stenopic view of the selective factors in the evolution of physical dormancy in seeds. Seed Science Research 25, 127-137.

Jayasuriya, K.M.G.G., Baskin, J.M. and Baskin, C.C. (2009) Sensitivity cycling and its ecological role in seeds with physical dormancy. Seed Science Research 19, 3-13.

Jayasuriya, K.M.G.G., Wijetunga, A.S.T.B., Baskin, J.M. and Baskin, C.C. (2013) Seed dormancy and storage behaviour in tropical Fabaceae: a study of 100 species from Sri Lanka. Seed Science Research 23, 257-269.

Kauffman, J.B., Cummings, D.L. and Ward, D.E. (1994) Relationships of fire, biomass and nutrient dynamics along a vegetation gradient in the Brazilian Cerrado. Journal of Ecology 82, 519-531.

Keeley, J.E., Pausas, J.G., Rundel, P.W., Bond, W.J. and Bradstock, R.A. (2011) Fire as an evolutionary pressure shaping plant traits. Trends in Plant Science 16, 406-411.

Knox, K.J.E. and Clarke, P.J. (2006) Fire season and intensity affect shrub recruitment in temperate sclerophyllous woodlands. Oecologia 149, 730-739.

Lakon, G. (1949) The topographical tetrazolium method for determining the germination capacity of seeds. Plant Physiology 24, 389-394.

Le Stradic, S., Silveira, F.A.O., Buisson, E., Cazelles, K., Carvalho, V. and Fernandes, G.W. (2015) Diversity of germination strategies and seed dormancy in herbaceous species of campo rupestre grasslands. Austral Ecology 40, 537-546.

Liyanage, G.S. and Ooi, M.K.J. (2017) Do dormancybreaking temperature thresholds change as seeds age in the soil seed bank? Seed Science Research. doi: 10.1017/ S0960258516000271.

Miranda, A.C., Miranda, H.S., Dias, I.F.O and Dias, B.F.S. (1993) Soil and air temperatures during prescribed cerrado fires in Central Brazil. Journal of Tropical Ecology $\mathbf{9}$, 313-320. 
Miranda, H.S., Sato, M.N., Neto, W.N. and Aires, F.S. (2009) Fires in the cerrado, the Brazilian savanna. In Cochrane, M.A. (ed), Tropical Fire Ecology: Climate change, Land Use and Ecosystem Dynamics, pp. 427-450. Berlin: Springer-Praxis.

Moreira, B. and Pausas, J.G. (2012) Tanned or burned: the role of fire in shaping physical seed dormancy. PLoS ONE 7, e51523.

Moreira, B., Tormo, J., Estrelles, E. and Pausas, J.G. (2010) Disentangling the role of heat and smoke as germination cues in Mediterranean Basin flora. Annals of Botany 105, 627-635.

Moreno-Casasola, P., Grime, J.P. and Martínez, M.L. (1994) A comparative study of the effects of fluctuations in temperature and moisture supply on hard coat dormancy in seeds of coastal tropical legumes in Mexico. Journal of Tropical Ecology 10, 67-86.

Oliveira-Filho, A.T. and Ratter, J.A. (2002) Vegetation physiognomies and woody flora of the Cerrado biome. In Oliveira, P.S. and Marquis, R.J. (eds), The Cerrados of Brazil: Ecology and Natural History of a Neotropical Savanna, pp. 91-120. New York: Columbia University Press.

Ooi, M.K.J., Denham, A.J., Santana, V.M. and Auld, T.D. (2014) Temperature thresholds of physically dormant seeds and plant functional response to fire: variation among species and relative impact of climate change. Ecology and Evolution 4, 656-671.

Parr, C.L., Lehmann, C.E.R., Bond, W.J., Hoffmann, W.A. and Andersen, A.N. (2014) Tropical grassy biomes: misunderstood, neglected, and under threat. Trends in Ecology and Evolution 29, 205-213.

R Core Team (2016) R: A language and environment for statistical computing. R Foundation for Statistical Computing, Vienna, Austria. Available at: https://www.R-project.org/

Ramos-Neto, M.B. and Pivello, V.R. (2000) Lightning fires in a Brazilian savanna national park: Rethinking management strategies. Environmental Management 26, 675-684.

Reyes, O. and Trabaud, L. (2009) Germination behaviour of 14 Mediterranean species in relation to fire factors: smoke and heat. Plant Ecology 202, 113-121.

Ribeiro, L.C., Barbosa, E.R.M., van Langevelde, F. and Borghetti, F. (2015) The importance of seed mass for the tolerance to heat shocks of savanna and forest tree species. Journal of Vegetation Science 26, 1102-1111.
Rolston, M.P. (1978) Water impermeable seed dormancy. The Botanical Review 44, 365-396.

Santana, V.M., Baeza, M.J. and Blanes, M.C. (2013) Clarifying the role of fire heat and daily temperature fluctuations as germination cues for Mediterranean Basin obligate seeders. Annals of Botany 111, 127-134.

Santana, V.M., Bradstock, R.A., Ooi, M.K.J., Denham, A.J., Auld, T.D. and Baeza, M.J. (2010) Effects of soil temperature regimes after fire on seed dormancy and germination in six Australian Fabaceae species. Australian Journal of Botany 58, 539-545.

Scott, K., Setterfield, S., Douglas, M. and Andersen, A. (2010) Soil seed banks confer resilience to savanna grasslayer plants during seasonal disturbance. Acta Oecologica 36, 202-210.

Simon, M.F., Grether, R., Queiroz, L.P., Skema, C., Pennington, R.T. and Hughes, C. (2009) Recent assembly of the Cerrado, a neotropical plant diversity hotspot, by in situ evolution of adaptations to fire. Proceedings of the National Academy of Sciences USA 106, 20359-20364.

van Assche, J.A., Debucquoy, K.L.A. and Rommens, W.A.F. (2003) Seasonal cycles in the germination capacity of buried seeds of some Leguminosae (Fabaceae). New Phytologist 158, 315-323.

van Klinken, R.D., Flack, L.K. and Pettit, W. (2006) Wetseason dormancy release in seed banks of a tropical leguminous shrub is determined by wet heat. Annals of Botany 98, 875-883.

van Klinken, R.D. and Goulier, J.B. (2013) Habitat-specific seed dormancy-release mechanisms in four legume species. Seed Science Research 23, 181-188.

Whelan, R.J. (1995) The Ecology of Fire. Cambridge, UK: Cambridge University Press.

Willis, C.G., Baskin, C.C., Baskin, J.M., Auld, J.R., Venable, D.L., Cavender-Bares, J., Donohue, K., Casa, R.R. and The NESCent Germination Working Group (2014) The evolution of seed dormancy environmental cues, evolutionary hubs, and diversification of the seed plants. New Phytologist 203, 300-309.

Zupo, T., Baeza, M.J. and Fidelis, A. (2016) The effect of simulated heat-shock and daily temperature fluctuations on seed germination of four species from fire-prone ecosystems. Acta Botanica Brasilica 30, 514-519. 